\title{
Clout goes to College: Admissions scandal at The University of Illinois at Urbana-Champaign
}

\author{
Adem BAYAR* \\ Department of Educational Science, College of Education, Amasya University
}

\begin{tabular}{|c|c|}
\hline \multicolumn{2}{|c|}{ College of Education, University of Missouri-Columbia, USA } \\
\hline Article history & \multirow{7}{*}{$\begin{array}{l}\text { There is no doubt that most people in the world want to continue their } \\
\text { education either undergraduate level or graduate level in the United States. } \\
\text { To do that, application is the first and most important request. After } \\
\text { applying for getting acceptance, the applicants must be patient and wait till } \\
\text { hearing from university. This process takes some considered time and is } \\
\text { named "admission process". However, a scandal happened at the University } \\
\text { of Illinois at Urbana-Champaign a few years ago. This event has caused } \\
\text { some serious debates regarding universities' admission policy and } \\
\text { admission processes. In order to touch this undesired event, the researchers } \\
\text { have conducted this current study. Therefore, the purpose of this study is to } \\
\text { bring up the admissions scandal at the university of Illinois at Urbana- } \\
\text { Champaign. In order to reach the aim of this study, the researchers have } \\
\text { tried to reach the answer of following research questions: } 1 \text {. What is the } \\
\text { scandal at the university of Illinois at Urbana-Champaign? and } 2 \text {. What did } \\
\text { people think and/or say about this scandal? In order to collect data, the } \\
\text { researchers have employed a qualitative research design in this study with } \\
\text { document analysis technique. Based on analyzing the collected data, the } \\
\text { researchers have come to the conclusion that nobody approves this event } \\
\text { and some people had resigned from their assignment after this event. }\end{array}$} \\
\hline $\begin{array}{l}\text { Received: } \\
29.11 .2014\end{array}$ & \\
\hline $\begin{array}{l}\text { Received in revised form: } \\
05.01 .2015\end{array}$ & \\
\hline $\begin{array}{l}\text { Accepted: } \\
06.01 .2015\end{array}$ & \\
\hline Kev words: & \\
\hline & \\
\hline & \\
\hline
\end{tabular}

\section{Introduction}

In this chapter, the researchers will introduce the university of Illinois at UrbanaChampaign. After that, the researchers will provide some information about the case that dramatically happened at the University of Illinois at Urbana-Champaign.

\subsection{The University of Illinois at Urbana-Champaign (UIUC)}

The University of Illinois at Urbana-Champaign (UIUC) was founded as one of the 37 land grant institutions in 1867, after President A Lincoln signed the Morrill Act of 1862. It opened in 1868 as Illinois Industrial University and was renamed the University of Illinois in 1885.

\footnotetext{
*Correspondence: adembayar80@gmail.com
} 
It is located in the twin cities, Urbana and Champaign, in east central Illinois, approximately 140 miles south of Chicago and 180 miles north east of St Louis. There are currently 17 colleges and instructional units at the current campus. In 2012, 32,000 students applied, 16, 211 interviews were conducted on the campus, and 6,914 freshman enrolled. There are 32,281 undergraduate from 50 states (4,447 International students) and 12,239 graduate students on the campus, for a total of 44,520 students of which $55 \%$ are male, $45 \%$ female, $14 \%$ are Asian-American, $7 \%$ Latino/a, 5\% African American, 2\% Multiracial, and 14\% are International (Facts-UIUC, 2013).

\subsection{The Case}

Imagine with us that you are a hard working high school senior with a competitive academic record, the child of middle income parents who make too much for scholarships, but not enough for the private or out of state college or university tuition, and you want to continue your education at your state's public university which is within your budget (Chicago Tribune, May 31, 2009). As an Illinois resident you complete the process of application of applying to UIUC. Unfortunately, you are declined admission. What would you do?

On May 29, 2009, the Chicago Tribune began a series of articles "Clout goes to college". The four part series made the front pages on May 29, 2009 through June 1, 2009 in which the admissions scandal at the University of Illinois at Urbana-Champaign was brought public. The Chicago Tribune secured, through the freedom of information act (TFIA), over 1800 pages of documents from university officials detailing admission favoritism for over 800 students during the admission season 2005-2009. The applicants with clout are known as Category 1 applicants. For example, in the 2008-2009 admission year approximately $77 \%$ of the applicants on the clout list were admitted, compared with $69 \%$ of the general pool of applicants for the entering freshman class. In this admission year there were 26,000 applicants of which 160 were on the 'Clout List'. Continued investigation noted that a) university officials knew that certain applicants were under qualified and admitted them anyway, b) admission officials complained but their objections were over-ruled, c) university trustees lobbied for "preferred students" who were friends, neighbors, and relatives, d) politicians sent admission requests to university lobbyists whose job depended on pleasing the lawmakers, and e) university officials often delayed admission notifications to 'weak' candidates until the end of the school year to minimize the fallout from top feeder high schools.

In one case, a relative of Tony Rezko was admitted against the decision of the admission committee. But, after the president (B. Joseph White at that time) sent an email to the campus chancellor (Richard Herman), who then forwarded the e-mail to the admissions officers, the decision for rejection was reversed. The e-mail explained that the governor (former Governor $\mathrm{R}$ Blagojevich) expressed his support for this applicant. The decision to reject this Rezko relative was based on the admission policy at the time. The admissions officer stated, "He's actually pretty low" after reviewing his ACT scores and other credentials (Chicago Tribune, May 29, 2009).

President B. Joseph White stated that it was not unusual for selective universities to review information about applicants from interested parties and the Category 1 list allows the university officers to track the application requests. While President White declined to address a specific case, he said "I would never support admission of a student over better qualified students simply because of connections and pressure". Documents also noted that the officer of enrollment 
management (Keith Marshall) was concerned about taking a big hit for putting a less qualified Category 1 applicant ahead of a more qualified applicants (Chicago Tribune May 31, 2009).

The governor of Illinois, Pat Quinn, called for an independent review and formed the Admissions Review Commission. This commission looked at 9,000 pages of documents, interviewed over 40 individuals, and conducted 12 public hearings during June and July of 2009. The report was submitted to the governor August 6, 2009. In the 45 page document, the commission concluded that much went astray in the admissions process at the UIUC campus and also noted that there was cause for optimism that the University can implement necessary and meaningful changes to restore the public's confidence in the integrity of the admissions process.

\section{The purpose and research questions of this study}

The purpose of this study is to bring up the admissions scandal at the university of Illinois at Urbana-Champaign. In order to do that the researchers have addressed the following research questions:

(1) What is the scandal at the university of Illinois at Urbana-Champaign?

(2) What did people think and/or say about this scandal?

This paper looks closely at the admissions scandal at the university. Therefore, the results of this study have special importance to policy makers interested in making policy for admissions at university level, faculty, researchers, and educators interested in teaching at university, and students interested in applying for getting acceptance for undergraduate or graduate level education in the United States. Moreover, this paper is informative for the readers of the journal to teach more about one of the most discussed events that affecting people' confidence to the universities and their admissions policy.

\section{Literature Review - Institution Types}

Various models have been used to describe institutions of higher education. Birnbaum (1988) defines five models for describing organizational functioning: a) Collegial, b) Bureaucratic, c) Political, d) Anarchical, and e) Cybernetic.

The collegial model, as applied to an institution of higher education, assumes and generally expects that the community of scholars operate with respect for each other and spends time to deliberate to reach consensus for problem solving. Problem solving is based on professional knowledge and competence rather than rules and politics. This is manifested through lack of or minimal hierarchy, elected (not appointed) leadership, and the norms of the culture are valued aspects of the relationships among the faculty and administration. The common backgrounds, values, norms, and traditions among the individuals provide a catalyst for building and maintaining the valued relationships between the individuals in the collegial environment (Birnbaum, 1988; Tierney, 2004).

The bureaucratic model, as applied to an institution of higher education, assumes and generally expects that the community of scholars and administrators operate through the chain of command 
(hierarchy) using rules and regulations with coordinated divisions of labor. There may be general collegiality, especially in the subunits or division comprising the working units within the institution, but there appears to be a lack of system-wide culture that unites faculty and administration. The organizational chart (few or many levels of hierarchy) is often related to the institutional values and processes. Success and rewards are generally linked with compliance with rules and regulations (Birnbaum, 1988; Tierney, 2004).

The political model, as applied to an institution of higher education, assumes and generally expects that the community of scholars and administrators operate through give-and-take, bargaining, and conflict resolution. From the political lens, institutions generally seek to acquire, develop, and use power to secure the desired outcomes. The use of power is often necessary for managing internal affairs as well as dealing with external stakeholders and system-wide problem solving. Resolving conflict and solving problems often produce tension between administrative/legal authority and the professional authority. Then the answer is often achieved through the formation of coalitions as generally no one individual or group has all the power (Birnbaum, 1988; Tierney, 2004). Birnbaum (1988) indicates that a key characteristic is that most of the time, most individuals or groups are not concerned (or are indifferent) to most of the issues in the organization.

The anarchical model, as applied to an institution of higher education, assumes and generally expects that the community of scholars and administrators deal with "issues and rationality" (Birnbaum, 1988, p 153) as they give their attention to a limited number of concerns within their environment. Their rationality is limited or bounded by their ability to make sense of or give meaning to the elements within their part of the organization. Poorly understood or problematic goals coupled with unclear technology and fluid participation by the stakeholders leads to decision making processes that are unclear. This often leads to conflict and strife for which the available people must decide available solutions at the time the decision/solution is needed. Consensus is not sought, rules and regulations are often ignored or reshaped, but the 'work of the day' is to link/connect the current problem with the available solutions as decided by those who are present at the time.

The cybernetic model, as applied to an institution of higher education, assumes and generally expects that the community of scholars and administrators deal with issues through self-correcting mechanisms the monitor various functions and use negative feedback to the individuals or groups when things are unstable or not going well. Birnbaum (1989) termed this as 'cybernetic controls'. There are organizational thermostats that use feedback loops to make minor and major adjusts as needed by involving the necessary individuals and groups for the subsystem that is out of alignment. Thus, coalitions are temporal and context driven. Loyalties are to the mission and vision of the institution or the subunit within the institution. In this model, the problem is addressed implementing a solution and monitoring the change or lack or change. Solutions are tried until one is found that provides the desired result. Each subunit, however, understands or realizes that it is acting, not alone, in concert with other subunits within the organization to maintain organizational balance and stability. The leadership, in this model, pays attention to what is going wrong by developing effective and efficient communication tools to inform them, after which they can act for the good of the organization (Birnbaum, 1988; Birnbaum, 1989). Perhaps Dr Melvin Konner (1987, p 21) is correct by providing the following instructions for all types of leaders and managers: a) "if it's working - let it be", b) “if it's not working - stop doing it", and c) 
“if you don't know what to do - don't do anything."

\section{Methodology}

The researchers have employed a qualitative research design in this study. To this end, the researchers have made document analysis technique throughout this study. For this aim, the researchers first collected the newspapers regarding the admissions scandal. Second, the researchers have carefully read all news about scandal. Third and lastly, the researchers have cited and/or quoted different people' thoughts concerning the scandal from the collected newspapers.

In order to see almost all related people' sound about this scandal, the researchers have more likely included the following stakeholders: 1. The students, 2 . The parents and residents, 3 . The alumni, 4. The faculty, 5. Admission's officers, 6. Chancellor Richard Herman, 7. President B. Joseph White, 8. Board of Trustees. 9. The lobbyists and politicians, and 10. The governor.

\section{Findings and Discussion}

Based on analyzing the collected data with respect of each stakeholder, the researchers have reached some findings from newspapers.

The stakeholders involved the students applying to the institution, the parents of the students as citizens of the State of Illinois, the alumni, the faculty at the institution, the various levels of administrators charged with the management of the day to day operations of the institution, the chancellor at the UIUC campus, the president of the university system, the members of the board of trustees, the lobbyists in the UIUC governmental affairs office, the senators and representatives involved in the clout scandal, the former governor ( $\mathrm{R}$ Blagojevich), the current governor (Pat Quinn), and all the people of the State of Illinois who through their taxes supported, among other causes as deemed appropriate by the state legislature, the University of Illinois at all four campuses.

\subsection{The students}

Paul Schmitt, student trustee for the UIUC campus, stated in a news release (Maternowski, 2009) that the university officials should act quickly to remove the Blagojevich taint by removing all the trustees appointed by the former governor. By starting this action the 'culture of corruption' could be reversed. It is interesting to consider this because the appointment of the trustees is from the governor and not the university officials. Other students participated in Facebook and Twitter exchanges, replied to Blogs, or just considered their luck to have been admitted to the UIUC campus as freshman. Many, though, had the prevailing idea that it is business as usual to regard entry into the University of Illinois at Urbana-Champaign as 'who you know' and not 'what you know' (Chicago Tribune, August 24, 2009).

\subsection{The parents and residents}

Residents of the State of Illinois responded to the scandal by indicting the board of trustees along with the politicians who interfered with the admissions process (News Gazette, July 17, 2009). The Chicago Tribune (Sept 5, 2009) polled 700 residents of the state and noted that $35 \%$ 
blamed the trustees, $26 \%$ blamed legislators and other elected officials, and $17 \%$ blamed university officials for the scandal. Another poll, with a $4 \%$ margin for error, conducted by Market Shares Corp. of Arlington Heights, from August 27-31, 2009 noted that $80 \%$ of respondents thought it was a common practice for universities to give preferential treatment to 'well-connected' applicants.

\subsection{The alumni}

In an open letter (News Gazette, July 12, 2009), to Governor Quinn, alumni David Olien urged the governor to step in and create change for new leadership prior to the start of the new academic year. He reviewed the history and culture of the campus and the impact that the state's culture of political corruption had on the flagship of the University of Illinois system. He specifically outlined seven steps to correct the corruption.

\section{4. The faculty}

Sixteen faculty from the law school sent an open letter to the Chicago Tribune that was published July 6, 2009. In this document the 16 signatories outlined the various elements of the scandal 'overlooked' by the Chicago Tribune. They asserted that the University of Illinois is often held hostage to the public purse controlled by the politicians. In other words, those with financial power use it. Next, the line between proper and improper influence on admission decisions is often difficult and vague and easily over-stepped by well-intentioned administrators. They noted that there are various levels of influence at all levels of the admissions process and in their opinion a "rational and moral admissions policy is one that minimizes the influence of these merit-unrelated factors without hoping to eliminate such influences entirely" (Chicago Tribune, July 6, 2009). However, on September 14, 2009, the Faculty Senate of the Urbana-Champaign campus approved a resolution calling for the removal of the university system president, B. Joseph White, and the campus chancellor, Richard Herman (The Chronicle of Higher Education, September 2009).

\subsection{Admission's officers}

It is the job of the admissions officers to apply the university admission policy to all applicants in a fair and equitable manner. Sometimes however, such as in this case, the admissions officers are 'instructed' to reverse the decisions for denial for some applicants. Keith Marshall, officer of enrollment management, was concerned about taking a big hit for putting a less qualified Category 1 applicant ahead of a more qualified applicants (Chicago Tribune May 31, 2009). Interestingly, Illinois State University President - Al Bowman, located in Bloomington-Normal, states that ISU does not have any type of clout or category 1 list of applicants (Pantagraph, June 2, 2009).

\subsection{Chancellor Richard Herman}

The chancellor, in testimony before the state investigative panel, accepted responsibility for the 'shadow' admission system that favored some applicants (Chicago Tribune, Aug 12, 2009). While sorry for his role in the admissions scandal, Chancellor Herman initially vowed to work toward creating a new admissions process. It wasn't until August 31, 2009, after the Admission 
Review Commission had issued its findings (August 6, 2009) that Chancellor Herman apologized to the Faculty Senate. On October 20, 2009 he resigned (The New York Times, October 21 2009).

\subsection{President B. Joseph White}

At first, he denied there was a problem: "What outside pressure? There is no outside pressure." Then, he minimized the problem: "Only an infinitesimal percentage of our admissions are tainted by special treatment. Besides, this goes on everywhere". Finally, he blamed the subordinates: "We'll straighten out those renegades in the admissions office." Later after the facts were brought to light, he finally admitted that there was a problem and promptly vowed to fix it. The clout list was suspended which by many was regarded as good news to the residents of the State of Illinois and by others as the opportunity to clean up the admissions process (News Gazette, June 5, 2009).

Less than a week after the Admissions Review Commission issued its findings, President B. Joseph White pledged to impose an eight-week deadline to implement the Commission's recommended reforms including the recommendation to build a 'fire-wall' around the admissions professionals and the admission's process to protect them from influential outsiders. September 23, 2009, President White announced his resignation effective December 31, 2009. The Board of Trustee chairman, Christopher Kennedy, appointed by the governor in early September 2009, stated that President White was not asked to resign nor did the Commission's report recommend that he president resign (News Gazette, Sept 24, 2009).

The University of Illinois Urbana-Champaign board of trustees chairman, Christopher Kennedy announced that the board had chosen a trusted leader from its past to serve as interim president of the university. Stanley Ikenberry led the university system from 1979 to 1995 and was the president of the American Council on Education from 1996 to 2001 (The Chronicle of Higher Education, October 4, 2009).

\subsection{Board of trustees}

As a result of the Admissions Review Commission report, trustee L Eppley was the first to resign. In a letter to the governor, he explained that the governor should be able to appoint a new team to rebuild the credibility of the university. Shortly thereafter, board chairman, Niranjan Shah admitted he exerted undue influence in the admissions process and resigned. In total, seven of the nine members of the board resigned following additional evidence of their influence in the admissions process (Business Insights, July 29, 2009; Chicago Tribune, August 4, 2009; The Chronicle of Higher Education, August 18, 2009). In response to the Commission's report the university officials and trustees issued a joint statement that the "admissions process must be fair to all applicants, the process must be transparent, and the process must offer equality of access" (Inside Higher Education, August 7, 2009).

\subsection{The lobbyists and politicians}

Several politicians and lobbyists were noted to have 'assisted' subpar applicants gain admission into the University of Illinois at Urbana-Champaign. The Commission noted that 114 elected officials logged 480 admission requests of the 800 applicants on the Category 1 list from 
2005-2009. It is not known exactly how many of these 'admission requests' resulted in actual acceptances (Chicago Tribune, June 11, 2009). Many of the politicians argue that the practice of assisting applicants is part of the "constituent services" provided by politicians in their district (Chicago Tribune June 21, 2009). After additional investigation the Chicago Tribune (May 5, 2010) identified that House Speaker Mike Madigan swayed university officials to admit 28 applicants whose relatives and political allies contributed $\$ 115,200$ to campaign funds he controls.

\subsection{The governor}

Governor Pat Quinn launched an investigation by appointing Abner Mikva, a retired federal judge, to lead the Admissions Review Commission. The governor charged the commission with examining the manner in which lawmakers, trustees, and university officials have used political persuasion to assist subpar applicants gain admission into the University of Illinois at Urbana-Champaign. The State of Illinois Admissions Review Commission (August 6, 2009) report called for all nine trustees to resign and in total seven resigned. Additional recommendations included shielding the admissions process and individuals from outside influences, developing a code of conduct for trustees and university officials, and suggested procedures for appointing trustees. The report did not call for the resignations of President White or Chancellor Herman.

\section{Conclusion}

This case points of the dangers inherent in organizations that rely on various stakeholders for their success in continuing to carry out the mission and vision of the organization, especially when there are competing interests. The leadership of all the stakeholders must align themselves with regard to the culture, mission, and values of the organization to protect the integrity of the organization.

\section{References}

Anonymous. (2009, May 29). Clout and college: U. of I. applicants may have gotten special consideration. Chicago Tribune. Retrieved from: http://articles.chicagotribune.com/200905-29/news/0906010101_1_admissions-applicants-antoin-tony-rezko

Anonymous. (2009, May 31). The scandal at rezko U. Chicago Tribune. Retrieved from: http://search.proquest.com/docview/356660773?accountid=14576

Anonymous. (2009, June 2) U of I ends political admissions list; ISU hasn't compiled one. Pantagraph. Retrieved from: http://search.proquest.com/docview/252743816?accountid=14576

Anonymous. (2009, June 5). UI admissions get once-over. News Gazette. Retrieved from: http://search.proquest.com/docview/332820041 ?accountid=14576

Anonymous. (2009, June 21). How about Clout U.? Chicago Tribune. Retrieved from: http://search.proquest.com/docview/356632613?accountid=14576

Anonymous. (2009, July 17). Unless the trustees go, nothing will change. News Gazette. Retrieved from: http://search.proquest.com/docview/333057229?accountid=14576

Anonymous. (2009, September 14). Faculty Senate Calls for Removal of U. of Illinois Leaders. The Chronicle of Higher Education. Retrieved from: http://chronicle.com/blogs/ticker/faculty-senate-calls-for-removal-of-u-of-illinoisleaders/8045 
Anonymous. (2013). Facts| Illinois. Retrieved from: http://illinois.edu/about/overview/facts/facts.html

Beckett, S., Dash, L., Finkin, M., Freyfogle, E., Garuopa, N., Hurt, C., ...Ulen, T. (2009, July 7). An open letter to the Chicago Tribune. Chicago Tribune. Retrieved from: http://www.chicagotribune.com/news/chi-open-letter-college-clout,0,1222515.htmlstory

Birnbaum, R. (1988). How Colleges work. San Francisco, CA: Jossey-Bass

Birnbaum, R. (1989). The cybernetic institution: Toward an integration of governance theories. Higher Education. 18(2). pp. 239-253

Cohen, J. (2009, August 12). University of Illinois chancellor apologizes for the scandal. Chicago Tribune. Retrieved from: http://search.proquest.com/docview/457730453?accountid=14576

Cohen, J. (2009, September 5). U of I. admissions scandal hurts reputation, poll finds: Illinois residents blame university trustees most. Chicago Tribune. Retrieved from: http://search.proquest.com/docview/420860905? accountid=14576

Cohen, J., St. Clair, S., Kidwell, D. \& Chase, J. (2010, May 5). House Speaker Michael Madigan swayed University of Illinois to admit relatives of allies, donors. Chicago Tribune. Retrieved from: http://articles.chicagotribune.com/2010-05-05/news/ct-met-madiganadmissions-20100505_1_relatives-28-applicants-law-school

Fitzsimmons, E. (2009, October 21). Chancellor at U. of Illinois quits in admissions scandal. The New York Times. Retrieved from: http://search.proquest.com/docview/434210492?accountid=14576

Huckabee, C (2009, August 18). 4 More trustees offer to resign From U. of Illinois board. The Chronicle of Higher Education. Retrieved from: http://chronicle.com/blogs/ticker/4-moretrustees-offer-to-resign-from-u-of-illinois-board/7735

Huckabee, C. (2009, October 4). U. of Illinois turns to a leader form its past as interim president. The Chronicle of Higher Education. Retrieved from: http://chronicle.com/blogs/ticker/u-ofillinois-turns-to-a-leader-from-its-past-as-interim-president/8326

Jaschik, S. (2009, August 7). Damning report on Illinois scandal. Inside Higher Ed. Retrieved from:

http://www.insidehighered.com/news/2009/08/07/illinois?width=775\&height=500\&iframe $=$ true

Konner, M. (1987). Becoming a doctor: a journey of initiation in medical school. New York, NY: Viking/Sifton Books

Malone, T. \& St. Clair, S. (2009, June 11). Quinn puts panel to work. Chicago Tribune. Retrieved from: http://search.proquest.com/docview/420780350?accountid=14576

Malone, T. \& Clair, S. (2009, June 11). Pressure is on for U. of I. probe. Chicago Tribune. Retrieved from: http://search.proquest.com/docview/420851697? accountid=14576

Malone, T., St. Clair, S. \& Cohen, J. (2009, August 4). University of Illinois board chairman quits amid scandal: Niranjan Shah resigns with review panel set to upbraid him over admissions. Chicago Tribune. Retrieved from: http://search.proquest.com/docview/464302944? accountid=14576

Malone, T. \& St. Clair, S. (2009, September 5). University of Illinois scandal: Gov. Pat Quinn appoints 4 new trustees. Quinn also reappoints Edward McMillan, who was not involved in the admission abuses. Chicago Tribune. Retrieved from: http://articles.chicagotribune.com/2009-09-05/news/0909040457_1_appoints-admissionsillinois 
Maternowski, K. (2009, June 1). Blago-style admissions. Inside Higher Ed. Retrieved from: http://www.insidehighered.com/news/2009/06/01/illinois?width=775\&height=500\&iframe $=$ true

McLoughlin, K \& Mulcahy, B. (2009, July 29). U. Illinois: U. Illinois board member resigns following scandal. Business Insights: Essentials. Retrieved from: http://bi.galegroup.com/essentials/article/GALE\%7CA204797431/fc12e0da058a264adba63 b4e5fb15829? $\mathrm{u}=$ morenetuomcolum

Mikva, A., Estrada, R., Judge, B., Lowry, D., Scholz, C., Scott, Z. \& Weele, M. (2009, August 6).

Report \& Recommendations. State of Illinois Admissions Review Commission. Retrieved from: http://www2.illinois.gov/gov/admissionsreview/Pages/default.aspx

Olien, D. (2009, July 12). An open letter to the governor: Restoring the UI. News Gazette. Retrieved from: http://search.proquest.com/docview/332906576?accountid=14576

Simmons, D. (2009, August 24). U. of I. students on campus react to clout admissions scandal. Chicago Tribune. Retrieved from: http://articles.chicagotribune.com/2009-0824/news/0908230462_1_graduate-campus-minority-students

Tierney, W. (1988). Organizational culture in higher education: defining the essentials. The Journal of higher Education. 59(1). pp. 2-21. Retrieved from: http://www.jstor.org/stable/1981868

Tierney, W. (2004). A cultural analysis of shared governance: The challenges ahead. Higher Education: Handbook of Theory and Research (Vol. 19, pp. 85-132). Norwell, MA: Kluwer Academic

Wurth, J. (2009, September 24). White out. News Gazette. Retrieved from: http://search.proquest.com/docview/332864586?accountid=14576 